\title{
Resting $\left[\mathrm{Ca}^{2+}\right]_{i}$, depolarizing GABA and possible role of local estradiol synthesis in the developing male and female hippocampus
}

\author{
Joseph L. Nuñez ${ }^{a}{ }^{*}$ and Margaret M. McCarthya,b \\ a Department of Physiology, University of Maryland, Baltimore, Baltimore, MD, 21201 \\ b Department of Psychiatry, Program in Neuroscience, University of Maryland, Baltimore, Baltimore, MD, \\ 21201
}

\section{Abstract}

The maturation of the hippocampus is impacted by a multitude of factors, including the regulation of intracellular calcium levels. Depolarizing actions of GABA can profoundly alter intracellular calcium in immature hippocampal neurons via influx through voltage gated calcium channels. We here report fundamental sex differences in properties of depolarizing GABA responses and in resting intracellular calcium in neonatal cultured hippocampal neurons. The effects of the ER antagonist, ICI 182,780, and the estradiol-synthesis inhibitor, formestane, indicate the sex differences in depolarizing GABA responses are at least in part due to de novo estradiol synthesis by female neurons, whereas a sex difference in resting calcium is independent of steroids. We postulate that local estradiol synthesis in cultured female hippocampal neurons affects the kinetics of either the $\mathrm{GABA}_{\mathrm{A}}$ receptor or voltage sensitive calcium channels. These data highlight the fact that immature hippocampal neurons exhibit fundamentally different physiological properties in males versus females. Elucidating how and where immature male and female neurons differ is essential for a complete understanding of normal brain development.

\section{Keywords}

Excitatory GABA; sex differences; steroid hormones

There are sex differences in hippocampal anatomy but the differences are generally small (Isgor and Sengelaub, 1998; Madeira and Lieberman, 1995) and inconsistent (Barteshagi et al., 2003; Galea et al., 1999) when compared to the robust and reliable anatomical sex differences in the diencephalon (Gorski et al., 1980; Simerly et al., 1984;Amateau and McCarthy, 2002; Mong and McCarthy, 2002). Intriguingly, the small neuroanatomical sex differences in hippocampal size do not correlate well with the magnitude of the hippocampaldependent behavioral sex differences (Jacobs et al., 1990), which can be large (Nuñez et al., 2000; Isgor and Sengelaub, 2003; Jonasson, 2005; Sava and Markus, 2005). Moreover, in the adult stressful conditions can reveal latent sex differences in both morphology and behavior

\footnotetext{
*Correspondence should be addressed to: Joseph Nuñez, Neuroscience Program and Department of Psychology, Michigan State University, 108 Giltner Hall, East Lansing, MI 48824, USA. Tel: +1-517-353-5201; Facsimile: +1-517-432-2744. Email: nunezj@msu.edu.

Publisher's Disclaimer: This is a PDF file of an unedited manuscript that has been accepted for publication. As a service to our customers we are providing this early version of the manuscript. The manuscript will undergo copyediting, typesetting, and review of the resulting proof before it is published in its final citable form. Please note that during the production process errors may be discovered which could affect the content, and all legal disclaimers that apply to the journal pertain.
} 
that are not otherwise apparent (Shors et al., 2001; Shors, 2006), but this has not been demonstrated for other brain regions. Thus, there is reason to consider that sex differences in the hippocampus are of a fundamentally different nature than those in the hypothalamus. The framework for analysis of sex differences in the hippocampus has traditionally been the Organizational/Activational hypothesis (Phoenix et al., 1959), with the assumption that the male hippocampus is actively organized by gonadal steroids while the female hippocampus is the default. We recently reported that the fundamental basis for the Organizational/Activational hypothesis of steroid-mediated sex differentiation of the brain, which is that males have higher neuronal estradiol levels, is not true in the telencephalon. Instead, the estradiol concentration in the hippocampus and frontal cortex of newborn females is equal to that of males (Amateau et al., 2004). Converging evidence suggests that in contrast to the peripheral origin of steroids, estradiol can also be synthesized in neurons or astrocytes de novo from cholesterol, (Ivanova and Beyer, 2000; Holloway and Clayton, 2001; Schlinger et al., 2001; Kretz et al., 2004; Prange-Kiel and Rune, 2005), including the developing female hippocampus (Amateau et al., 2004).

Immature hippocampal neurons maintain high (relative) intracellular chloride, resulting in membrane depolarization following $\mathrm{GABA}_{\mathrm{A}}$ receptor activation (Ben-Ari et al., 2002; Ganguly et al., 2001; Leinekugel et al., 1995; LoTurco et al., 1995; Obrietan and van den Pol, 1995), leading to calcium influx via L-type voltage sensitive calcium channels (Ben-Ari et al., 2002; Nuñez et al., 2005; Obrietan and van den Pol, 1995). This GABA mediated excitation impacts on synaptogenesis and neuronal maturation during the first 10 to 14 days of life (Behar et al., 1996; Manent et al., 2005; Represa and Ben-Ari, 2005). Estradiol enhances the depolarizing actions of GABA such that the magnitude of the calcium transient in response to bolus application of the $\mathrm{GABA}_{\mathrm{A}}$ agonist muscimol is increased, and so is the percentage of cells that respond to GABA as depolarizing. Continued exposure to estradiol delays the developmental shift from depolarizing to hyperpolarizing GABA action (Perrot-Sinal et al., 2001; Nuñez et al., 2005). Given the central role of estradiol in determining morphometric sex differences in the brain, we hypothesized that estradiol enhancement of depolarizing GABA would subserve this function in the hippocampus. However, the observation that endogenous estradiol levels do not differ between males and females negated this possibility.

Taken together, these previous observations raise two fundamental questions; 1 ) are there sex differences in the hippocampus and if so, how are they determined?, and 2) do steroid hormones impact on hippocampal development in males and females, and if so, how do they differ? In order to address these questions, we have employed the use of sex-specific day-of-birth primary cultures of hippocampal neurons. This approach deprives the neurons of a gonadal source of steroids and allows for an examination of the impact of both exogenous steroid application and endogenous steroidogenesis intrinsic to the cultured neurons and glia. We find that male and female principal neurons differ in fundamental properties such as resting intracellular calcium and the response to $\mathrm{GABA}_{\mathrm{A}}$ receptor activation. These parameters are modulated by steroids in a complex manner that suggests de novo synthesis of estradiol by female neurons and requires a rethinking of how sex differences in the hippocampus develop. Moreover, these data imply that the rules governing sexual differentiation of diencephalic structures do not apply to at least one structure in the telencephalon, the hippocampus.

\section{EXPERIMENTAL PROCEDURES}

\section{Tissue Preparation and Treatment}

Newborn (postnatal day 0) male and female rats (Sprague-Dawley, Charles River Labs, Wilmington, MA, USA) were obtained from breeder females. From each litter, equal numbers of males and females were collected. Animal use procedures were approved by the University of Maryland, Baltimore Institutional Animal Care and Use Committee, and followed National 
Institute of Health guidelines. In all procedures, tissue from male and female rats remained separate. Hippocampal neurons were cultured according to previously established procedures (Nuñez et al., 2005). Briefly, hippocampi were dissected into HBSS+ [88ml sterile $\mathrm{H}_{2} \mathrm{O}, 10$ $\mathrm{ml}$ Hank's balanced salt solution $\left(\mathrm{Ca}^{2+}\right.$ and $\mathrm{Mg}^{2+}$-free) 10X, $1 \mathrm{ml}$ HEPES buffer, $1.0 \mathrm{M}$, pH 7.3, $1 \mathrm{ml}$ antibiotic/antimycotic 100X liquid], then additional HBSS + was added to the tube to a volume of $4.5 \mathrm{ml}$, with $0.5 \mathrm{ml}$ trypsin $(2.5 \%)$, and incubated 15 minutes at $37^{\circ} \mathrm{C}$. Supernatant was discarded and tissue washed twice with HBSS+, dissociated by trituration, plated on $25 \mathrm{~mm}$ Poly-L-lysine coated cover slips at a density of 300,000 cells per coverslip, and placed in $100 \mathrm{~mm}$ dishes containing $4 \mathrm{ml}$ plating medium [ $86 \mathrm{ml}$ MEM, $10 \mathrm{ml}$ horse serum, $3 \mathrm{ml}$ glucose (filter sterilized, $20 \%$ ) $1 \mathrm{ml}$ pyruvic acid, $100 \mathrm{mM}$ ]. We have previously explored short duration exposure time to horse serum ( 2 hour) and found no effects on calcium dynamics following muscimol exposure, but a small and significant effect on cell viability. We have also attempted to culture neurons in the absence of serum with a profound reduction in cell viability, therefore serum was retained. Cell number and viability were determined by trypan blue exclusion and allowed 4 hours to adhere to the coverslips in a $37^{\circ} \mathrm{C}, 5 \% \mathrm{CO}_{2}$ incubator. Coverslips were removed from the plating dishes and placed into $35 \mathrm{~mm}$ dishes filled with Neurobasal+ $[1 \mathrm{ml}$ B-27 supplement, $1 \mathrm{ml}$ Antibiotic/Antimycotic 100X, 125 $\mu \mathrm{l}$ L-Glutamine and filled to $50 \mathrm{ml}$ with Neurobasal (phenol red free)]. All cell culture chemicals and solutions were obtained from Invitrogen (Carlsbad, CA, USA). Treatments were on days in vitro (DIV) 0 and 1 and included one of the following six agents: 1 ) $1 \mathrm{nM} 17 \beta$-Estradiol (E2 - estrogen receptor $\alpha / \beta$ agonist) 2 ) $1 \mathrm{nM}$ PPT (selective estrogen receptor $\alpha$ agonist) 3) 1nM DPN (selective estrogen receptor $\beta$ agonist), 4) $1 \mathrm{nM}$ ICI 182,780 (ICI - estrogen receptor $\alpha / \beta$ antagonist), 5) $1 \mathrm{nM}$ formestane (Form - aromatase inhibitor), or 6 ) DMSO (vehicle $<0.5 \%$ by volume). A separate set of hippocampal cultures were treated on DIV 1 ( 24 hours prior imaging) or DIV 2 ( 8 hours prior imaging) with $1 \mathrm{nM}$ ICI 182,780 . The concentration of $17 \beta$-estradiol was chosen because it approximates high physiological levels of estradiol (Nuñez and McCarthy, 2003), with equimolar concentrations of all other estrogen receptor agonists and antagonists. The recently developed agonists, PPT and DPN, with specificity for estrogen receptor $\alpha(\mathrm{ER} \alpha)$ and $\beta$ $(\mathrm{ER} \beta)$, respectively, have markedly lower affinity for the receptor than $17 \beta$-estradiol itself. PPT has half the binding affinity of $17-\beta$ estradiol for the receptor, but has a 400 -fold higher affinity for ERa than ER $\beta$ (Stauffer et al., 2000). DPN, on the other hand, has only a 70-fold higher affinity for ER $\beta$ over ER $\alpha$ and can activate ER $\alpha$ at high concentrations (Meyers et al., 2001). An equimolar concentration of both PPT and DPN was used to allow for a direct comparison to $17 \beta$-estradiol and to avoid the induction of any non-specific effects of these compounds.

\section{Calcium Imaging in Cultured Hippocampal Neurons}

Cells underwent calcium imaging on day in vitro (DIV) 2 or DIV 7 according to previously established protocol (Nuñez et al., 2005; 2007). Briefly, hippocampal neurons were incubated for 30 min at RT with the cell permeant fluorescent indicator Fura-2-AM ( $3 \mu \mathrm{M}$; Molecular Probes, Eugene, OR, USA) in DMSO $(<0.5 \%)$ before transfer to a tissue chamber mounted on a microscope stage, and superfusion with physiological salt solution (PSS: $140 \mathrm{mM} \mathrm{NaCl}, 5 \mathrm{mM}$ $\mathrm{KCl}, 1.2 \mathrm{mM} \mathrm{Na}_{2} \mathrm{PO}_{4}, 1.4 \mathrm{mM} \mathrm{MgCl}_{2}, 1.8 \mathrm{mM} \mathrm{CaCl}_{2}, 11.5 \mathrm{mM}$ glucose, $10 \mathrm{mM}$ HEPES; $\mathrm{pH}=7.4)$ at $32-34^{\circ} \mathrm{C}$ to remove extracellular dye and allow for esterification of Fura-2-AM. All drugs (see below) were administered in the superfusate. The imaging system consists of a Zeiss Axiovert 100 inverted microscope, with illumination provided by a Till Photonics Polychrome II Monochromator (Applied Scientific Instrumentation, Eugene, OR, USA), a Hamamatsu CCD video camera and image intensifier. Image acquisition and analysis was performed with the Metamorph/Metafluor Imaging System, version 5.0 (Universal Imaging Corporation, Downingtown, PA, USA). Cells in the field of view were characterized morphologically using a 60X objective, making a distinction between neurons and glia. On a typical coverslip, the ratio of neurons to glia is $4: 1$. Individual cells were chosen for analysis 
by the investigator and traced using the Metafluor program. Numerous criteria were used to distinguish neurons from glia, but the most important was shape - the somas of pyramidal neurons are triangular in appearance with rounded and clearly distinct edges. Neurons usually possess at least two primary processes. In contrast, glial cells are amorphous in shape, with flat and non-distinct edges and no distinct processes. Only data obtained from neurons was included. Baseline measurement of resting intracellular calcium concentration for individual cells was obtained over a 5-minute period while the cells were superfused with PSS. A total of 15 images (one every 20 seconds) were collected over the five minute baseline acquisition period. The baseline value for an individual cell was the average value of the 15 images. This was followed by a 50 second pulse of the $\mathrm{GABA}_{\mathrm{A}}$ receptor agonist, muscimol $(10 \mu \mathrm{M})$, with data acquired for a further 5 to 7 minutes (allowing for re-establishment of baseline calcium levels). During presentation of muscimol, images were collected every second. A subset of the hippocampal cultures were administered muscimol across a range of concentrations $(2 \mu \mathrm{M}$, $5 \mu \mathrm{M}, 10 \mu \mathrm{M}$ and $50 \mu \mathrm{M})$. Starting with the lowest concentration $(2 \mu \mathrm{M})$, hippocampal neurons were administered a 50 second pulse of muscimol, followed by 5 minutes of PSS. This process was repeated for all four concentrations. A separate set of coverslips were treated with

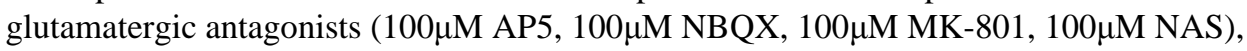
voltage sensitive calcium channel blockers $(10 \mu \mathrm{M}$ diltiazem, $1 \mu \mathrm{M} \omega$-Conotoxin GVIA, $1 \mu \mathrm{M}$ nimodipine), or intracellular and extracellular calcium chelators (500 $\mu \mathrm{M}$ EGTA [in the presence of calcium free PSS], $1 \mu \mathrm{M}$ BAPTA-AM, $1 \mu \mathrm{M}$ CPA) for 7 minutes prior to the test solution (muscimol) application.

The following parameters were documented during calcium imaging: 1) average baseline intracellular calcium concentration, 2) peak intracellular calcium concentration following muscimol application, 3) number of cells responding with muscimol-induced calcium transients (a calcium response is defined as a change in the level of intracellular calcium to at least $10 \%$ greater than the baseline intracellular calcium level), 4) time to attain peak intracellular calcium concentration (rise time), and 5 ) time following muscimol application required to re-attain one-half baseline intracellular calcium concentration (decay time). In the analysis, cells were grouped into one of three classifications: 1) non-responders, 2) cells with increases in intracellular calcium responses between 10-75\% greater than baseline ["low" responders], and 3) cells with increases in intracellular calcium responses $75 \%$ and greater than baseline ["high" responders]. Intracellular calcium concentration was calculated from the ratio of the background corrected Fura- 2 emission $(520 \mathrm{~nm})$ at two excitation wavelengths $(340 \mathrm{~nm} /$ $380 \mathrm{~nm}$ ) by in situ solution calibration (Nuñez et al., 2005), performed using a calcium calibration buffer concentration kit (Molecular Probes, Eugene, OR, USA).

\section{Radioimmunoassay of Estradiol Levels in Male and Female Hippocampal Cultures}

Hippocampal tissue from two separate litters of newborn male and female rats was cultured and used to assess estradiol levels. A subset of the cultures was treated with either 1nM estradiol or $0.33 \mathrm{nM}$ estradiol on the day of culturing. Five hundred microliters of media was collected individually from each male and female hippocampal culture on PN1. Media was housed in a $-80{ }^{\circ} \mathrm{C}$ freezer until processing for quantification of estradiol by radioimmunoassay (RIA). Samples were shipped on dry ice and underwent RIA for estradiol at the Center for Cellular and Molecular Studies, University of Virginia (Charlottesville, VA). The commercially available Diagnostic Systems Lab (Webster, TX) $3^{\text {rd }}$ Generation Estradiol RIA kit was used. The maximum sensitivity of this assay is $2.5 \mathrm{pg} / \mathrm{ml}$. The estradiol assay had an intra-assay variability of less than $5.7 \%$ and an inter-assay variability of less than $7.2 \%$. Each sample was run in duplicate. 


\section{Western Blot Analysis of Cultured Hippocampal Neurons}

Tissue for Western blot analysis was obtained from culture dishes containing day in vitro two female hippocampal cells. Cells were collected from two separate culture runs, with six samples from each of the following three groups: 1) 1nM 17ß-Estradiol, 2) 1nM ICI 182,780, and 3) DMSO (vehicle). Hippocampal cell-containing culture dishes were placed on ice, with $75 \mu \mathrm{l}$ of ice-cold lysis buffer containing 50mM Tris-HCl, $1 \%$ Na-deoxycholate, $0.25 \%$ NP-40, 150 $\mathrm{mM} \mathrm{NaCl}, 1 \mathrm{mM}$ EDTA and protease inhibitors $(1 \mu \mathrm{g} / \mathrm{ml}$ of aprotinin, leupeptin, and pepstatin; $1 \mathrm{mM}$ phenylmethylsulfonyl fluoride) added to each dish. Cells were scraped off of the coverslips and collected along with the liquid. Samples were centrifuged at 3,000× $\mathrm{g}$ for 30 minutes at $-10^{\circ} \mathrm{C}$. The supernatant fraction was collected, and the protein concentration determined by Bradford assay. Twenty micrograms of total protein from each animal were electrophoresed on a SDS-polyacrylamide gel (8-16\% Tris glycine) and transferred to a polyvinylidenedifluoride membrane. Membranes were washed with 0.1M TBS and blocked for 1 hour at room temperature in $0.1 \mathrm{M}$ TBS containing 5\% nonfat dry milk. Membranes were then incubated with a either a rabbit $\mathrm{R} 5$ monoclonal antibody generated against the phosphorylated form of the mouse $\mathrm{Na}^{+} \mathrm{K}^{+} 2 \mathrm{Cl}^{-}$co-transporter NKCC1 protein (1:2500; generous gift of Dr. Biff Forbush, Yale University, New Haven CT), or a mouse monoclonal antibody generated against the housekeeping gene, GAPDH (1:10,000; Chemicon, Temecula, CA). All antibodies were diluted in TBS containing $0.05 \%$ Tween-20 (TBS-T), and incubated for 3 hours at room temperature. Membranes were incubated in goat anti-rabbit or rabbit antimouse HRP-linked secondary antibody (1:3000, Cell Signaling Technology, Beverly, MA) for 30 minutes at room temperature, and then washed with TBS-T. Immunoreactive bands were detected using an enhanced chemiluminesence kit (ECL kit, New England Biolabs, Beverly, MA) and membranes were exposed to film (Hyperfilm-ECL. Amersham Pharmacia Biotech, Arlington Heights, IL). The proteins were detected as a band of specific molecular masses $(\mathrm{pNKCC} 1=162 \mathrm{kDa} ; \mathrm{GAPDH}=37 \mathrm{kDa})$, and the integrative grayscale pixel area-density (iad) was captured with a CCD camera and analysis performed on a Macintosh computer using the public domain NIH Image program (developed at the U.S. National Institutes of Health and available at http://rsb.info.nih.gov/nih-image/). In order to control for gel loading, iad values for pNKCC1 were divided by GAPDH. A total of five samples were analyzed per group for all Western blot analyses.

\section{Statistical Analysis}

For calcium imaging, data in a field of view was collected from all cells classified as neurons. In each field of view, there were a minimum of 10 neurons. If this criterion was not satisfied, another field of view was chosen. Data collected from one field of view was averaged to avoid biases due to the number of neurons in a field of view or characteristics of a field of view. Each individual field of view was then treated as an independent $n$. The number of neurons analyzed in the current set of experiments is consistent with previous reports that investigated ratiometric imaging in cultured cells (Canepari et al., 2007; Lang et al., 2007; Meier et al., 2008; Santiago et al., 2008). Two-way analysis of variance for the effect of sex and age of the hippocampal cultures was performed on baseline (resting) intracellular calcium concentration. Two-way analyses of variance for the effect of sex and treatment were performed on the antagonist effects on baseline intracellular calcium concentration, antagonist effect on peak muscimol-induced increase in intracellular calcium concentration, rise time and decay time. One-way analysis of variance for the effect of sex was performed on peak intracellular calcium concentration following muscimol $(10 \mu \mathrm{M})$ application. Two-way analysis for the effect of treatment and sex was performed on peak intracellular calcium concentration following application of various concentrations of muscimol. One-way analysis of variance for the effect of treatment was performed on Western blot analysis of pNKCC1 protein levels. $\chi^{2}$ tests were run on the percent of cells responding with calcium transients. For all ANOVAs and post-hoc (Tukey's) tests, a level of $\mathrm{p}<0.05$ was required to obtain statistical significance. 


\section{RESULTS}

\section{Baseline intracellular calcium is higher in females than males}

Cultured hippocampal neurons maintain a relatively constant intracellular calcium concentration at rest (with less than $1 \%$ variance over the five minute baseline acquisition period). We used Fura-2 ratiometric imaging to estimate the free, baseline (resting) intracellular calcium concentration $\left(\left[\mathrm{Ca}^{2+}\right]_{\mathrm{i}}\right)$. Representative photomicrographs of pseudocolored images of male and female hippocampal neurons during calcium imaging are presented in Figures 1B and $1 \mathrm{C}$, respectively. In Figure 1A, we document a significant effect of the sex of the hippocampal cultures on baseline $\left[\mathrm{Ca}^{2+}\right]_{i}$ with female hippocampal neurons having significantly higher baseline $\left[\mathrm{Ca}^{2+}\right]_{\mathrm{i}}$ than male hippocampal neurons on day in vitro (DIV) 2 (ANOVA: $\mathrm{F}_{1,19}=40.57, \mathrm{p}<0.0001$ ). Data was obtained from 5-6 culture runs, with 1-2 fields of view per culture run for a total $n$ of $10-12$.

\section{Extracellular calcium influx provides higher resting levels in females}

In an attempt to ascertain the source of the sex difference in baseline intracellular calcium, we used glutamate receptor antagonists and blockers of calcium entry, intracellular calcium release, and calcium chelators (both intracellular and extracellular). The approach was to distinguish external versus internal sources of calcium entry/release and determine which was the critical parameter establishing the higher baseline $\left[\mathrm{Ca}^{2+}\right]_{\mathrm{i}}$ in female hippocampal neurons. Treatments included: 1) ionotropic glutamate receptor antagonists, including the NMDA receptor antagonists AP5, MK-801, and the AMPA receptor antagonist NBQX $(100 \mu \mathrm{M}), 2)$ calcium channel blocker diltiazem $(10 \mu \mathrm{M})$ (Dobrev et al., 1999), 3) ionotropic glutamate receptor antagonists plus diltiazem, 4) calcium sequestering agent, EGTA $(500 \mu \mathrm{M})$, in calcium free PSS, 5) intracellular calcium chelator, BAPTA-AM $(1 \mu \mathrm{M})$, or 6$)$ intracellular calcium reuptake inhibitor CPA $(1 \mu \mathrm{M})$. Drugs were administered for seven minutes, followed by three minutes of PSS which allowed for a return to baseline. Data in Figure 1D are presented as the average $\left[\mathrm{Ca}^{2+}\right]_{i}$ obtained across the seven min antagonist application. There was a significant effect of treatment $\left(\mathrm{F}_{6,32}=28.31 ; \mathrm{p}<0.001\right)$, sex $\left(\mathrm{F}_{1,32}=10.74 ; \mathrm{p}<0.01\right)$ and a treatment by sex interaction $\left(\mathrm{F}_{6,32}=2.59 ; \mathrm{p}=0.018\right)$ on the average $\left[\mathrm{Ca}^{2+}\right]_{\mathrm{i}}$. There was no effect of antagonism of ionotropic glutamate receptors, blocking VSCCs, or the combination of blocking VSCCs and ionotropic glutamate receptors on the average $\left[\mathrm{Ca}^{2+}\right]_{\mathrm{i}}$ in hippocampal neurons of either sex. Both BAPTA-AM and CPA significantly decreased the average $\left[\mathrm{Ca}^{2+}\right]_{\mathrm{i}}$ in both males and females. The largest effect was observed following EGTA in calcium free PSS, resulting in an $8-10 \%$ drop in resting calcium in male hippocampal neurons and a significantly greater 14 to $17 \%$ drop in female hippocampal neurons (Tukey's, $\mathrm{p}<0.01$ ). Thus, the predominant regulator of baseline intracellular calcium is passive calcium entry from extracellular sources and this may be the mechanism for the sex difference given that female hippocampal neurons responded with a greater drop in intracellular calcium following application of EGTA in calcium free PSS than did males. Why females respond more strongly than males to a change in extracellular sources of calcium is unknown. Data was obtained from five culture runs, with 1 to 2 fields of view per culture run for a total $n$ of $5-10$ per group.

\section{There is a sex difference in magnitude of muscimol-induced calcium transients}

In sex-specific hippocampal cultures generated on the day of birth (Figure $2 \mathrm{~A}$ and $2 \mathrm{~B}$ ), the peak calcium response in "high responding" (those with responses greater than $75 \%$ above the intracellular calcium concentration) of DIV 2 female neurons was greater than in male neurons following bath application of $10 \mu \mathrm{M}$ muscimol $\left(\mathrm{F}_{1,5}=9.27 ; \mathrm{p}<0.006\right)$. There was no significant difference between male and female hippocampal neurons in the magnitude of calcium responses in the "low responding" (those with responses between 10 and $75 \%$ above the intracellular calcium concentration) neurons (Figure 2A and 2B). Data was obtained from three culture runs per sex and per group, with 2 fields of view per culture run for an $n$ of 6 . 
Histogram of calcium responses from individual male and female hippocampal neurons are shown in Figure 2B. Data were obtained from 55 responding male and female hippocampal neurons from one culture run. Representative traces from individual male and female hippocampal neurons are shown in Figure 3.

In examining the response of male and female hippocampal neurons to various concentrations of muscimol $(2 \mu \mathrm{M}, 5 \mu \mathrm{M}, 10 \mu \mathrm{M}$ and $50 \mu \mathrm{M})$, we observed no sex by treatment interaction on the sensitivity to calcium responses (data not shown). At all concentrations examined, female hippocampal neurons displayed significantly larger magnitude muscimol-induced calcium responses than male hippocampal neurons $\left(\mathrm{F}_{1,24}=18.21 ; \mathrm{p}<0.001\right)$. Data was obtained from three culture runs per sex, per group, with 2 fields of view per culture run for an $n$ of 6 for each sex at each muscimol dose.

\section{Effect of sex, inhibition of aromatase or antagonism of the estrogen receptor on the magnitude and percent of cells responding with muscimol-induced calcium transients}

Along with the sex difference in peak calcium response, there was a significant effect of sex $\left(\chi^{2}=6.51 ; p<0.02\right)$ and treatment $\left(\chi^{2}=4.89 ; \mathrm{p}<0.04\right)$ on the percent of cells responding with muscimol-induced calcium transients (data not shown). There were $10 \%$ more female hippocampal neurons responding with muscimol-induced calcium transients than male hippocampal neurons, with the sex difference eliminated by pretreatment with the estrogen receptor antagonist ICI 182,780 or the estrogen synthesis inhibitor formestane. In contrast, neither ICI 182,780 nor formestane had an effect on the percent of male hippocampal neurons responding with calcium transients. Data was obtained from three culture runs, with two fields of view per culture run for an $n$ of 6 .

In contrast, there was no effect of treatment on the peak magnitude of the muscimol-induced calcium transients (data not shown). Neither formestane, nor 8 and 24 hour ICI 182,780 pretreatment significantly affected the peak magnitude of the muscimol-induced calcium transients.

\section{The source of muscimol-induced calcium influx is the same in both sexes}

Given the sex difference in the peak magnitude of muscimol-induced calcium transients and percent of cells responding with muscimol-induced calcium transients on DIV 2, we were curious if this was due to an additional route of calcium entry in females that was not present in males. The approach was to determine if antagonism differentially affected the presence or magnitude of muscimol-induced calcium transients (Figure 2C). Treatments included: 1) ionotropic glutamate receptor antagonists, including the NMDA receptor antagonists AP5 and MK-801, and the AMPA receptor antagonist NBQX (100 $\mu \mathrm{M}$ for all drugs), 2) non-specific calcium channel blocker diltiazem $(10 \mu \mathrm{M})$, 4) L-type calcium channel blocker nimodipine $(1 \mu \mathrm{M}), 5) \mathrm{N}$-type calcium channel blocker $\omega$-Conotoxin GVIA $(1 \mu \mathrm{M}), 6)$ ionotropic glutamate receptor antagonists plus diltiazem, 7) calcium sequestering agent, EGTA $(500 \mu \mathrm{M})$, in calcium free PSS 5) intracellular calcium chelator, BAPTA-AM $(1 \mu \mathrm{M}), 8)$ intracellular calcium reuptake inhibitor CPA $(1 \mu \mathrm{M})$, and 9) sodium channel blocker, tetrodotoxin $(1 \mu \mathrm{M})$. Drugs were administered for seven minutes, followed by two minutes of concurrent administration with muscimol, followed by three minutes of PSS. Data are presented as the peak $\left[\mathrm{Ca}^{2+}\right]_{\mathrm{i}}$ obtained during the two minutes of concurrent muscimol and antagonist/blocker application. We documented a significant main effect of antagonist treatment $\left(F_{9,30}=10.17 ; p<0.007\right)$ on the magnitude of muscimol-induced calcium transients (Figure 2C). Diltiazem alone, nimodipine alone, and diltiazem in combination with the ionotropic glutamate receptor antagonists significantly blocked the increase in intracellular calcium following muscimol application (Tukey's, $\mathrm{p}<0.01$ ). Likewise, EGTA in calcium free PSS completely attenuated the increase in intracellular calcium following muscimol application (Tukey's, $\mathrm{p}<0.01$ ). 
There was only a modest effect (16-24\% blockade) of the muscimol-induced increase in intracellular calcium by $\omega$-Conotoxin GVIA. Ionotropic glutamate receptor antagonists alone, BAPTA-AM, CPA and tetrodotoxin were without effect on the peak magnitude of muscimolinduced calcium transients in hippocampal neurons from both males and females. Therefore, muscimol-induced increases in intracellular calcium in male and female hippocampal neurons result from external sources, with entry through VSCCs (predominantly L-type VSCCs), and the route of calcium entry is unaffected by sex. Data was obtained from three to four culture runs for each sex, with one to two fields of view per culture run for an $n$ of 4 to 8 .

\section{Rise and decay time in response to muscimol-induced calcium transients is shorter in female neurons and altered by blocking estrogen receptors or estradiol synthesis}

Following muscimol administration, $\mathrm{GABA}_{\mathrm{A}}$ receptor activation in the developing hippocampus results in chloride efflux and membrane depolarization sufficient to open VSCCs. The amount of time required to attain the maximal intracellular calcium concentration is reflective of the magnitude of $\mathrm{GABA}_{\mathrm{A}}$ receptor-mediated membrane depolarization, the number of VSCCs open and the kinetics of VSCCs. In Figure 4A, we report a significant effect of $\operatorname{sex}\left(\mathrm{F}_{1,28}=8.22 ; \mathrm{p}<0.02\right)$, treatment $\left(\mathrm{F}_{4,28}=19.23 ; \mathrm{p}<0.001\right)$, and a sex by treatment interaction $\left(\mathrm{F}_{4,28}=10.11 ; \mathrm{p}<0.005\right)$ on the latency to maximal intracellular calcium concentration following muscimol application. This value, which we define as rise time, was significantly faster in vehicle-treated females than both vehicle-treated males and the formestane (aromatase inhibitor) treated and ICI-182,780 (ER antagonist) treated female cultures, independent of time of ICI 182,780 treatment(Tukey's, $\mathrm{p}<0.01$ ). The observation that either blocking ER or inhibiting estradiol synthesis eliminated the female bias in faster rise time suggests the faster rise time in females is a function of de novo estradiol synthesis in the cultured female hippocampal neurons. Data were obtained from three culture runs for each sex, with two fields of view per culture run for an $n$ of 6 .

Following influx of calcium, cells re-establish homeostasis by calcium extrusion, or sequestration into organelles (Dayanithi et al., 2006; Siesjo, 1990). Calcium-induced calcium release from internal stores and buffering by calcium binding proteins can further affect the duration of elevated free intracellular calcium (Mattson et al., 1991). In Figure 4B, we document a significant effect of $\operatorname{sex}\left(\mathrm{F}_{1,28}=11.43 ; \mathrm{p}<0.005\right)$, treatment $\left(\mathrm{F}_{4,28}=20.14 ; \mathrm{p}<0.001\right)$, and a sex by treatment interaction $\left(\mathrm{F}_{4,28}=10.61 ; \mathrm{p}<0.01\right)$ on the time required to reduce the intracellular calcium concentration to one-half of baseline levels, defined as decay time. In the current experiment, muscimol application lasted for 50 seconds, with $\left[\mathrm{Ca}^{2+}\right]_{\mathrm{i}}$ recorded for 5 to 7 minutes post muscimol application. Male hippocampal neurons maintained elevated $\left[\mathrm{Ca}^{2+}\right]_{\mathrm{i}}$ for $87 \pm 2$ seconds post muscimol application. In contrast, female hippocampal neurons cleared $\left[\mathrm{Ca}^{2+}\right]_{\mathrm{i}}$ in $53 \pm 3$ seconds, $39 \%$ faster than male hippocampal neurons. This sex difference in decay time (as with rise time) appears to be related to de novo synthesis of estradiol in female hippocampal neurons. In female hippocampal neurons treated with the estrogen receptor antagonists ICI 182,780 (pretreatment for 24 or 48 hours) or the estradiol synthesis inhibitor formestane, decay time was equivalent to that in male hippocampal neurons. Pretreatment with ICI 182,780 for eight hours was without effect on decay time in female hippocampal neurons. Data was obtained from three culture runs per sex, with one to two fields of view per culture run, for an $n$ of 4 to 6 .

\section{Estradiol mediated enhancement of the magnitude of muscimol-induced calcium transients occurs via estrogen receptor $\alpha$}

There are at least two distinct isoforms of the estrogen receptor (ER) $-\alpha$ and $\beta$. The ER $\alpha$ and $\mathrm{ER} \beta$, selective agonists, PPT and DPN, were used to distinguish which receptor subtype(s) was mediating the observed effects of estradiol. In Figure 5A, we document a significant effect of treatment $\left(\mathrm{F}_{4,12}=23.12 ; \mathrm{p}<0.001\right)$ on the magnitude of muscimol-induced calcium transients 
in female hippocampal neurons. Pretreatment with 1nM DPN (ER $\beta$ selective agonist) had no significant effect on the magnitude of the muscimol-induced increase in intracellular calcium (relative to controls), while pretreatment with $1 \mathrm{nM}$ PPT (ER $\alpha$ selective agonist) significantly increased the magnitude of the muscimol-induced increase in intracellular calcium (58-67\% increase over baseline). The increase observed following PPT treatment was less than that seen with an equimolar concentration of 17 $\beta$-Estradiol (95-113\% increase over baseline), consistent with the lower affinity of PPT for ER $\alpha$. The combination of DPN plus PPT had an effect similar to PPT alone treatment. Data was obtained from three culture runs, with one to two fields of view per culture run with an $n$ of 4 to 6 .

\section{No detectable effect of sex on estradiol levels in the hippocampal culture media}

Radioimmunoassay was used to assess if the levels of estradiol produced by hippocampal cultures could be detected by conventional radioimmunoassay, and if the levels were significantly different between the sexes. Estradiol was not detectable in the untreated male and female hippocampal culture medium, suggesting any de novo synthesis was below the level of sensitivity of the assay (data not shown). As a positive control male and female cultures were treated with either $1 \mathrm{nM}$ estradiol or $0.33 \mathrm{nM}$ estradiol on the day of culturing. Culture medium was collected on DIV 1 . The $0.33 \mathrm{nM}$ estradiol treatment increased the levels of estradiol to $\sim 260$ and $\sim 275 \mathrm{pg} / \mathrm{ml}$ in male and female cultures, respectively. The $1 \mathrm{nM}$ estradiol treatment increased the level of estradiol to greater than $750 \mathrm{pg} / \mathrm{ml}$ - outside of the quantifiable range of the assay. Data was obtained from two culture runs, with media collected from three hippocampal cultures of each sex from each culture run (for the untreated male and female cultures), and two hippocampal cultures of each sex from each culture run (for the estradiol treated male and female cultures).

\section{Antagonism of the estrogen receptor alters chloride co-transporter levels in the developing hippocampus}

Western blot analysis of the impact of exogenous $17 \beta$-estradiol administration and antagonism of the estrogen receptor with ICI 182,780, on the phosphorylation of NKCC1 in the female rat hippocampus (Figure 5B) revealed a significant effect of treatment on $\mathrm{pNKCC1}$ protein levels $\left(\mathrm{F}_{2,12}=18.17 ; \mathrm{p}<0.005\right)$. ICI 182,780 pretreatment significantly decreased $\mathrm{pNKCC} 1$ protein, while exogenous estradiol did not have a significant effect on $\mathrm{pNKCC} 1$ protein levels (although the direction was toward increasing - post hoc Tukey's, $\mathrm{p}=0.07$ ), relative to vehicle treated females.

\section{DISCUSSION}

The current results demonstrate a fundamental sex difference in properties of depolarizing GABA responses and in resting intracellular calcium in neonatal cultured hippocampal neurons. The effects of the ER antagonist, ICI 182,780, and the estradiol-synthesis inhibitor, formestane, suggest the sex differences in depolarizing GABA responses are due to de novo estradiol synthesis by female neurons, whereas the sex difference in resting calcium is independent of steroids. The effects of estradiol appear to be mediated by the ER-alpha isoform and neuronal estradiol synthesis is hypothesized to be restricted to female hippocampal neurons, given the lack of effect of ICI 182,780 and formestane on male hippocampal neurons. However, we could not detect estradiol in the culture medium of either male or female cultured hippocampal neurons (see further discussion on this below). Nonetheless, these findings highlight the fact that developing cultured hippocampal neurons exhibit fundamentally different physiological properties. Elucidating how immature male and female neurons differ and whether current results extend to other areas of the brain is essential for a complete understanding of normal brain development. 
A central tenet in studies of sex differences in the brain is that genetic sex determines gonadal sex, and gonadal sex in turn determines brain sex via the actions of gonadal steroids acting on the brain in utero and during the early postnatal period (Arnold and Breedlove, 1985; Arnold and Gorski, 1984). Most sex differences in the brain of rodents result from the action of estradiol, the aromatized product of testosterone (Breedlove et al., 1999; McEwen et al., 1979), although androgens themselves have restricted and specific effects (Johansen et al., 2004; Han and DeVries, 2003; Zhang et al., 2008) and emerging evidence suggests a role for genes on the X or Y chromosome (DeVries et al., 2002; Arnold, 2004). There has been a clear precedent for de novo steroidogenesis impacting on sex differences in avian brain development (Holloway and Clayton, 2001), but this notion has been embraced by relatively few investigators studying the developing mammalian brain (Ivanova and Beyer, 2000; ToranAllerand et al., 2005). Moreover, the most celebrated sex differences in brain are the morphometric: volume of a particular region, neuron number, synapse density and dendritic elaboration (Davis et al., 1996, Isgor and Sengelaub, 1998; Madeira and Lieberman, 1995; Park et al., 1996; Raisman and Field, 1973). Limited work has attended to the basic physiological parameters of cells that may be affected by sex and/or developmental steroid hormones.

The level of intracellular calcium when a cell is nominally at rest is fundamental to its response profile following excitation. Local microdomains of calcium influx activate distinct signaling pathways (Bito et al., 1996; Deisseroth et al., 1998) and the magnitude of the change can determine the activation of kinases versus phosphatases (Dolmetsch et al., 2001; Mermelstein et al., 2000). The dynamics of calcium influx, release from internal stores, sequestration and extrusion, are played against a backdrop of baseline calcium, which we have found to be significantly higher in female versus male hippocampal neurons on day in vitro two. The relative magnitude of this sex difference is small $(2-5 \mathrm{nM})$, but when placed in the context of total resting calcium and the possible maximum range of differences between individuals of opposite sex, can constitute as much as $10-25 \%$ of the resting calcium differing between males and females. While few known calcium-sensing proteins are sensitive to a $2-5 \mathrm{nM}$ difference in calcium, the calcium binding protein calmodulin is a potential candidate. Calcium enhances the affinity of calmodulin for target proteins such as adenylyl kinase and other protein kinases (Xia and Storm, 2005). It has been demonstrated that at the $3-15 \mathrm{nM}$ range, calcium enhances the coupling of calmodulin to the myosin light chain kinase in rabbit skeletal muscle (Olwin et al., 1984). A similar sensitivity of calmodulin to nanomolar concentrations of calcium is thought to exist in the mammalian brain. This is hypothesized to occur following activation of voltage sensitive calcium channels (Xia and Storm, 2005), the main route of calcium into the cell following depolarizing GABA responses. The possibility of sex differences in calmodulin activation in developing hippocampal neurons exists, but has not been explored.

The mechanistic basis for the sex difference in resting calcium is unknown but possibilities include increased density of routes of calcium entry, duration of channel open times or kinetics related to calcium buffering, extrusion or sequestration. Using a cocktail of ionotropic glutamate receptor antagonists and diltiazem, a non-specific voltage-sensitive calcium channel blocker (Dobrev et al., 1999), we observed a small but significant decrement in baseline intracellular calcium concentration in both males and females. However, pharmacological blockade of calcium entry via these routes did not equalize resting calcium in females to that of males. Release of calcium from intracellular sources plays a crucial role in the regulation of intracellular calcium levels, illustrated by the dramatic effect of the intracellular calcium chelator BAPTA-AM and CPA on both male and female hippocampal neurons, but this manipulation also did not eliminate the sex difference in baseline intracellular calcium concentration. Importantly, female neurons were significantly more sensitive to changes in extracellular calcium concentration, suggesting external sources of calcium (outside of ligand- 
gated and voltage-sensitive mechanisms) play the primary role in maintaining higher resting calcium in female hippocampal neurons.

During development, GABA-mediated excitation (as opposed to inhibition) results from the balance of chloride co-transporter expression, including $\mathrm{NKCC} 1$ and $\mathrm{KCC} 2$, to regulate the transmembrane chloride concentration gradient (Delpire, 2002; Lu et al., 1999; Plotkin et al., 1997; Schwartz-Bloom and Sah, 2001). NKCC1 promotes chloride, sodium and potassium transport into cells and its expression is high in neonatal brain but declines with advancing age. Conversely, KCC2 promotes chloride and potassium extrusion from the cell and its expression is low neonatally but increases as development progresses. By the end of the second postnatal week, KCC2 levels are elevated, while NKCC1 levels are significantly decreased (Plotkin et al., 1997; Delpire, 2000). The developmental shift in KCC2 and NKCC1 is directly causally related to whether $\mathrm{GABA}_{\mathrm{A}}$ receptor activation results in depolarization and influx of calcium via VSCCs or hyperpolarization and synaptic inhibition (Lu et al., 1999; Payne et al., 2003; Plotkin et al., 1997; Rivera et al., 1999, 2004; Schomberg et al., 2003; Stein et al., 2004; Sun and Murali, 1999). We previously reported that estradiol treatment of mixed sex hippocampal cultures increases the protein levels of pNKCC1 (phosphorylated/active form of NKCC1), with no effect on KCC2 (Nuñez et al., 2005). These estradiol-induced changes in the chloride cotransporters would be predicted to result in higher relative chloride concentration inside the cell. We have more recently reported sex differences in the levels of the phosphorylated (active) form of NKCC1 (Perrot-Sinal et al., 2007), and now report that levels of pNKCC1 are decreased in female hippocampal neurons treated with the estrogen receptor antagonist ICI 182,780, supporting our hypothesis that de novo estradiol synthesis in females enhances depolarizing GABA action in the developing hippocampus.

Female hippocampal neurons on day in vitro two exhibit significantly greater magnitude calcium responses to the same dose of muscimol as compared to male hippocampal neurons. This may be due to a greater depolarization in female hippocampal neurons, or an additional source for increasing intracellular calcium. While electrophysiological investigation of the first possibility is outside the scope of the current study, we investigated the source (either extracellular or intracellular) of muscimol-induced increases in intracellular calcium. Calcium influx via voltage sensitive calcium channels is the exclusive means of increasing intracellular calcium following activation of the $\mathrm{GABA}_{\mathrm{A}}$ receptor, with no difference in the route/source of calcium entry between the sexes. We conclude that in response to muscimol, there may be a greater magnitude of depolarization in female as compared to male hippocampal neurons.

We hypothesize that de novo synthesis of estradiol by female hippocampal neurons may contribute to the elevated intracellular calcium response to muscimol on day in vitro two. This is based on the observation that treatment of female hippocampal cultures with either the estrogen receptor antagonist, ICI 182,780, or the aromatase inhibitor, formestane, reduced the magnitude of muscimol-induced calcium transients to that of control males, suggesting the greater magnitude response in females is at least partially mediated by increased depolarization subsequent to de novo estradiol synthesis. However, we could not detect estradiol in the medium of either male or female cultured hippocampal neurons using a highly sensitive RIA with a detection limit as low as $2.5 \mathrm{pg} / \mathrm{ml}$. Previous reports of estradiol being detected in the medium of cultured hippocampal neurons involved pooling of large quantities of medium after multiple days in vitro (Prange-Kiel et al., 2003). We have previously detected estradiol in the hippocampus of neonatal male and female rats in the $10-20 \mathrm{pg} / \mathrm{mg}$ protein range when measured by RIA (Amateau et al., 2004) but recent assays have detected less than $5 \mathrm{pg} / \mathrm{ml}$ (Konkle and McCarthy, unpublished observation). There are many caveats associated with quantification of estradiol by RIA and the risk of false positives is genuine. More specific quantification techniques, such as Time-of-Flight mass spectrometry, do not have the sensitivity to detect the apparently very small quantities of steroids that are produced. 
Nonetheless, multiple groups have reported consistent and specific effects of antagonism of the estrogen receptor and inhibition of aromatase activity on various endpoints including synaptogenesis (Mukai et al., 2006; Hu et al., 2007), axon growth (von Schassen et al., 2006) cell survival (Fester el al., 2006) and receptor levels (Prange-Kiel et al., 2003). It has recently been proposed that the regulation of local estradiol levels by aromatase plays a critical role in sex-specific brain development (Garcia-Segura, 2008). Aromatase, acting in a region and agespecific manner, may rapidly affect intracellular calcium levels, thereby playing an important role in the current findings (Garcia-Segura, 2008). In the current series of experiments, we have observed consistent effects of antagonism of ER and inhibition of aromatase activity on the depolarizing effects of GABA manifest as calcium transients in developing hippocampal neurons. The fact that we observe these effects selectively in female-specific cultures is consistent with the interpretation that only female neurons synthesis estradiol "in the dish" or de novo, but other interpretations of these results cannot currently be ruled out.

\section{CONCLUSIONS}

We conclude that basic physiological properties of immature hippocampal neurons are profoundly affected by sex and also possibly by local estradiol production. The sex-specific variations include fundamental parameters such as resting intracellular calcium, the magnitude of the depolarizing response to $\mathrm{GABA}_{\mathrm{A}}$ receptor activation and calcium-mediated rise time/ decay time in response to muscimol application. Although the current experiments have demonstrated that sex and estradiol clearly play a critical role in the developmental regulation of these responses, other factors (currently unknown) likewise may play important roles. Greater attention to the sex of neurons in primary culture preparations and a rethinking of the rules governing sex differentiation of the brain as applied to the telencephalon, are warranted.

\section{Acknowledgements}

This work was supported by National Institutes of Health grant NS050525-01 to MMM and National Institutes of Health grant MH 068347 to JLN.

\section{References}

Amateau SK, Alt JJ, Stamps CL, McCarthy MM. Brain estradiol content in newborn rats: sex differences, regional heterogeneity, and possible de novo synthesis by the female telencephalon. Endocrinology 2004;145:2906-2917. [PubMed: 14988386]

Amateau SK, McCarthy MM. Induction of PGE2 by estradiol mediates developmental masculinization of sex behavior. Nat Neurosci 2004;7:643-650. [PubMed: 15156148]

Arnold AP. Sex chromosomes and brain gender. Nat Rev Neurosci 2004;5:701-708. [PubMed: 15322528]

Arnold AP, Breedlove SM. Organizational and activational effects of sex steroids on brain and behavior: a reanalysis. Horm Behav 1985;19:469-498. [PubMed: 3910535]

Arnold AP, Gorski RA. Gonadal steroid induction of structural sex differences in the central nervous system. Annu Rev Neurosci 1984;7:413-442. [PubMed: 6370082]

Balthazart J, Baillien M, Charlier TD, Ball GF. Effects of calmodulin on aromatase activity in the preoptic area. J Neuroendocrinol 2005;17:664-671. [PubMed: 16159379]

Balthazart J, Cornil CA, Taziaux M, Charlier TD, Baillien M, Ball GF. Rapid changes in production and behavioral action of estrogens. Neuroscience 2006;138:783-791. [PubMed: 16359807]

Bartesaghi R, Guidi S, Severi S, Contestabile A, Ciani E. Sex differences in the hippocampal dentate gyrus of the guinea-pig before puberty. Neuroscience 2003;121:327-339. [PubMed: 14521992]

Behar TN, Li YX, Tran HT, Ma W, Dunlap V, Scott C, Barker JL. GABA stimulates chemotaxis and chemokinesis of embryonic cortical neurons via calcium-dependent mechanisms. J Neurosci 1996;16:1808-1818. [PubMed: 8774448] 
Ben-Ari Y. Excitatory actions of gaba during development: the nature of the nurture. Nat Rev Neurosci 2002;3:728-739. [PubMed: 12209121]

Bito H, Deisseroth K, Tsien RW. CREB phosphorylation and dephosphorylation: a Ca2+ and stimulus duration-dependent switch for hippocampal gene expression. Cell 1996;87:1203-1214. [PubMed: 8980227]

Breedlove SM, Cooke BM, Jordan CL. The orthodox view of brain sexual differentiation. Brain Behav Evol 1999;54:8-14. [PubMed: 10516400]

Canepari M, Djurisic M, Zecevic D. Dendritic signals from rat hippocampal CA1 pyramidal neurons during coincident pre- and post-synaptic activity: a combined voltage- and calcium imaging study. J Physiol 2007;580:463-484. [PubMed: 17272348]

Davis EC, Popper P, Gorski RA. The role of apoptosis in sexual differentiation of the rat sexually dimorphic nucleus of the preoptic area. Brain Res 1996;734:10-18. [PubMed: 8896803]

Dayanithi G, Mechaly I, Viero C, Aptel H, Alphadery S, Puech S, Bancel F, Valmier J. Intracellular Ca2 + regulation in rat motoneurons during development. Cell Calcium 2006;39:237-246. [PubMed: 16324742]

Deisseroth K, Heist EK, Tsien RW. Translocation of calmodulin to the nucleus supports CREB phosphorylation in hippocampal neurons. Nature 1998;392:198-202. [PubMed: 9515967]

Delpire E. Cation-Chloride Cotransporters in Neuronal Communication. News Physiol Sci 2000;15:309_ 312. [PubMed: 11390932]

DeVries GJ, Rissman EF, Simerly RB, Yang LY, Scordalakes EM, Auger CJ, Swain A, Lovell-Badge R, Burgoyne PS, Arnold AP. A model system for study of sex chromosome effects on sexually dimorphic neural and behavioral traits. J Neurosci 2002;22:9005-9014. [PubMed: 12388607]

Dobrev D, Milde AS, Andreas K, Ravens U. The effects of verapamil and diltiazem on N-, P- and Qtype calcium channel mediating dopamine release in rat striatum. British J Pharm 1999;127:576582.

Dolmetsch RE, Pajvani U, Fife K, Spotts JM, Greenberg ME. Signaling to the nucleus by an L-type calcium channel-calmodulin complex through the MAP kinase pathway. Science 2001;294:333-339. [PubMed: 11598293]

Fester L, Ribeiro-Gouveia V, Prange-Kiel J, von Schassen C, Bottner M, Jarry H, Rune GM. Proliferation and apoptosis of hippocampal granule cells require local oestrogen synthesis. J Neurochem 2006;97:1136-1144. [PubMed: 16579833]

Galea LA, Perrot-Sinal TS, Kavaliers M, Ossenkopp KP. Relations of hippocampal volume and dentate gyrus width to gonadal hormone levels in male and female meadow voles. Brain Res 1999;821:383391. [PubMed: 10064825]

Ganguly K, Schinder AF, Wong ST, Poo M. GABA itself promotes the developmental switch of neuronal GABAergic responses from excitation to inhibition. Cell 2001;105:521-532. [PubMed: 11371348]

Garcia-Segura LM. Aromatase in the brain: not just for reproduction anymore. J Neuroendocrinol 2008;20:705-712. [PubMed: 18601693]

Gorski RA, Harlan RE, Jacobson CD, Shryne JE, Southam AM. Evidence for the existence of a sexually dimorphic nucleus in the preoptic area of the rat. J Comp Neurol 1980;193:529-39. [PubMed: 7440781]

Han TM, DeVries GJ. Organizational effects of testosterone, estradiol and dihydrotestosterone on vasopressin mRNA expression in the bed nucleus of the stria terminalis. J Neurobiol 2003;54:502510. [PubMed: 12532400]

Holloway CC, Clayton DF. Estrogen synthesis in the male brain triggers development of the avian song control pathway in vitro. Nat Neurosci 2001;4:170-175. [PubMed: 11175878]

$\mathrm{Hu}$ R, Cai WQ, Wu XG, Yang Z. Astrocyte-derived estrogen enhances synapse formation and synaptic transmission between cultured neonatal rat cortical neurons. Neuroscience 2007;144:1229-1240. [PubMed: 17184929]

Isgor C, Sengelaub DR. Prenatal gonadal steroids affect adult spatial behavior, CA1 and CA3 pyramidal cell morphology in rats. Horm Behav 1998;34:183-198. [PubMed: 9799628]

Isgor C, Sengelaub DR. Effects of neonatal gonadal steroids on adult CA3 pyramidal neuron dendritic morphology and spatial memory in rats. J Neurobio 2003;55:179-190. 
Ivanova T, Beyer C. Ontogenetic expression and sex differences of aromatase and estrogen receptoralpha/beta mRNA in the mouse hippocampus. Cell Tissue Res 2000;300:231-237. [PubMed: 10867819]

Jacobs LF, Gaulin SJ, Sherry DF, Hoffman GE. Evolution of spatial cognition: sex-specific patterns of spatial behavior predict hippocampal size. Proc Natl Acad Sci U S A 1990;87:6349-6352. [PubMed: 2201026]

Johansen JA, Jordan CL, Breedlove SM. Steroid hormone masculinization of neural structure in rats: a tale of two nuclei. Physiol Behav 2004;83:271-277. [PubMed: 15488544]

Jonasson Z. Meta-analysis of sex differences in rodent models of learning and memory: a review of behavioral and biological data. Neurosci Biobehav Rev 2005;28:811-25. [PubMed: 15642623]

Kretz O, Fester L, Wehrenberg U, Zhou L, Brauckmann S, Zhao S, Prange-Kiel J, Naumann T, Jarry H, Frotscher M, Rune GM. Hippocampal synapses depend on hippocampal estrogen synthesis. J Neurosci 2004;24:5913-5921. [PubMed: 15229239]

Lang SB, Stein V, Bonhoeffer T, Lohmann C. Endogenous brain-derived neurotrophic factor triggers fast calcium transients at synapses in developing dendrites. J Neurosci 2007;27:1097-1105. [PubMed: 17267564]

Leinekugel X, Tseeb V, Ben-Ari Y, Bregestovski P. Synaptic GABAA activation induces Ca2+ rise in pyramidal cells and interneurons from rat neonatal hippocampal slices. J Physiol 1995;487:319-329. [PubMed: 8558466]

LoTurco JJ, Owens DF, Heath MJ, Davis MB, Kriegstein AR. GABA and glutamate depolarize cortical progenitor cells and inhibit DNA synthesis. Neuron 1995;15:1287-1298. [PubMed: 8845153]

Lu J, Karadsheh M, Delpire E. Developmental regulation of the neuronal- specific isoform of $\mathrm{K}-\mathrm{Cl}$ cotransporter KCC2 in postnatal rat brains. J Neurobiol 1999;39:558-568. [PubMed: 10380077]

Madeira MD, Lieberman AR. Sexual dimorphism in the mammalian limbic system. Prog Neurobiol 1995;45:275-333. [PubMed: 7624480]

Manent JB, Demarque M, Jorquera I, Pellegrino C, Ben-Ari Y, Aniksztejn L, Represa A. A noncanonical release of GABA and glutamate modulates neuronal migration. J Neurosci 2005;25:4755-4765. [PubMed: 15888651]

Mattson MP, Rychlik B, Chu C, Christakos S. Evidence for calcium- reducing and excito-protective roles for the calcium binding protein calbindin-D28k in cultured hippocampal neurons. Neuron 1991;6:4151. [PubMed: 1670921]

McEwen BS, Davis PG, Parsons B, Pfaff DW. The brain as a target for steroid hormone action. Annu Rev Neurosci 1979;2:65-112. [PubMed: 395885]

Meier SD, Kafitz KW, Rose CR. Developmental profile and mechanisms of GABA-induced calcium signaling in hippocampal astrocytes. Glia 2008;56:1127-1137. [PubMed: 18442094]

Mermelstein PG, Bito K, Deisseroth K, Tsien RW. Critical dependence of cAMP response element binding protein phosphorylation on L-type calcium channels supports a selective response to EPSPs in preference to action potentials. J Neurosci 2000;20:266-273. [PubMed: 10627604]

Meyers MJ, Sun J, Carlson KE, Marriner GA, Katzenellenbogen BS, Katzenellenbogen JA. Estrogen receptor-beta potency-selective ligands: structure-activity relationship studies of diarylpropionitriles and their acetylene and polar analogues. J Med Chem 2001;44:4230-4251. [PubMed: 11708925]

Mong JA, McCarthy MM. Ontogeny of sexually dimorphic astrocytes in the neonatal rat arcuate. Dev Brain Res 2002;139:151-8. [PubMed: 12480129]

Mukai H, Takata N, Iishi HT, Tanabe N, Hojo Y, Furakawa A, Kimoto T, Kawato S. Hippocampal synthesis of estrogens and androgens which are paracrine modulators of synaptic plasticity: synaptocrinology. Neuroscience 2006;138:757-764. [PubMed: 16310315]

Nuñez JL, Bambrick LL, Krueger BK, McCarthy MM. Prolongation and enhancement of GABA receptor mediated excitation by chronic treatment with estradiol in developing rat hippocampal neurons. Eur J Neurosci 2005;21:3251-3261. [PubMed: 16026463]

Nuñez JL, McCarthy MM. Estradiol exacerbates hippocampal damage in a model of preterm human infant brain injury. Endocrinology 2003;144:2350-2359. [PubMed: 12746295]

Nuñez JL, McCarthy MM. Evidence for an extended duration of GABA- mediated excitation in the developing male versus female hippocampus. Devel Neurobiol 2007;67:1879-1890. [PubMed: 17823921] 
Obrietan K, van den Pol AN. GABA neurotransmission in the hypothalamus: developmental reversal from Ca2+ elevating to depressing. J Neurosci 1995;15:5065-5077. [PubMed: 7623135]

Olwin BB, Edelman AM, Krebs EG, Storm DR. Quantitation of energy coupling between Ca2+, calmodulin, skeletal muscle myosin light chain kinase, and kinase substrates. J Biological Chem 1984;259:10940-10955.

Park JJ, Baum MJ, Paredes RG, Tobet SA. Neurogenesis and cell migration into the sexually dimorphic preoptic area/anterior hypothalamus of the fetal ferret. J Neurobiol 1996;30:315-328. [PubMed: 8807525]

Payne JA, Rivera C, Voipio J, Kaila K. Cation-chloride co-transporters in neuronal communication, development and trauma. Trends Neurosci 2003;26:199-206. [PubMed: 12689771]

Perrot-Sinal TS, Davis AM, Gregerson KA, Kao JP, McCarthy MM. Estradiol enhances excitatory gamma-aminobutyric [corrected] acid-mediated calcium signaling in neonatal hypothalamic neurons. Endocrinology 2001;142:2238-43. [PubMed: 11356668]

Perrot-Sinal TS, Sinal CJ, Reader JC, Speert DB, McCarthy MM. Sex differences in the chloride cotransporters, NKCC1 and KCC2, in the developing hypothalamus. J Neuroendocrinol 2007;19:302-308. [PubMed: 17355320]

Phoenix CH, Goy RW, Gerall AA, Young WC. Organizing action of prenatally administered testosterone propionate on the tissues mediating mating behavior in the female guinea pig. Endocrinology 1959;65:369-82. [PubMed: 14432658]

Plotkin MD, Snyder EY, Hebert SC, Delpire E. Expression of the Na-K-2Cl cotransporter is developmentally regulated in postnatal rat brains: a possible mechanism underlying GABA's excitatory role in immature brain. J Neurobiol 1997;33:781-795. [PubMed: 9369151]

Prange-Kiel J, Wehrenberg U, Jarry H, Rune GM. Para/autocrine regulation of estrogen receptors in hippocampal neurons. Hippocampus 2003;13:226-234. [PubMed: 12699330]

Prange-Kiel J, Rune GM. Direct and indirect effects of estrogen on rat hippocampus. Neuroscience 2005;29:1-10.

Raisman G, Field PM. Sexual dimorphism in the neuropil of the preoptic area of the rat and its dependence on neonatal androgen. Brain Res 1973;54:1-29. [PubMed: 4122682]

Represa A, Ben-Ari Y. Trophic actions of GABA on neuronal development. Trends Neurosci 2005;28:278-283. [PubMed: 15927682]

Rivera C, Voipio J, Payne JA, Ruusuvuori E, Lahtinen H, Lamsa K, Pirvola U, Saarma M, Kaila K. The $\mathrm{K}+/ \mathrm{Cl}-$ co-transporter KCC2 renders GABA hyperpolarizing during neuronal maturation. Nature 1999;397:251-255. [PubMed: 9930699]

Rivera C, Voipio J, Thomas-Crusells J, Li H, Emri Z, Sipila S, Payne JA, Minichiello L, Saarma M, Kaila $\mathrm{K}$. Mechanism of activity-dependent downregulation of the neuron-specific K-Cl cotransporter KCC2. J Neurosci 2004;24:4683-4691. [PubMed: 15140939]

Santiago AR, Carvalho CM, Carvalho AP, Ambrosio AF. Differential contribution of L-, N- and P/Qtype calcium channels to [Ca2+]i changes evoked by kainate in hippocampal neurons. Neurochem Res 2008;33:1501-1508. [PubMed: 18368487]

Sava S, Markus EJ. Intramaze cue utilization in the water maze: effects of sex and estrous cycle in rats. Horm Behav 2005;48:23-33. [PubMed: 15919382]

Schlinger BA, Soma KK, London SE. Neurosteroids and brain sexual differentiation. Trends Neurosci 2001;24:429-31. [PubMed: 11476868]

Schomberg SL, Bauer J, Kintner DB, Su G, Flemmer A, Forbush B, Sun D. Cross talk between the GABA (A) receptor and the Na-K-Cl cotransporter is mediated by intracellular $\mathrm{Cl}$. J Neurophysiol 2003;89:159-167. [PubMed: 12522168]

Schwartz-Bloom RD, Sah R. gamma-Aminobutyric acid(A) neurotransmission and cerebral ischemia. J Neurochem 2001;77:353-371. [PubMed: 11299298]

Shors TJ, Chua C, Falduto J. Sex differences and opposite effects of stress on dendritic spine density in the male versus female hippocampus. J Neurosci 2001;21:6292-7. [PubMed: 11487652]

Shors TJ. Stressful experience and learning across the lifespan. Annu Rev Psychol 2006;57:55-85. [PubMed: 16318589]

Siesjo BK. Calcium in the brain under physiological and pathological conditions. Eur Neurol 1990;30:39. [PubMed: 2180715] 
Simerly RB, Swanson LW, Gorski RA. Demonstration of a sexual dimorphism in the distribution of serotonin-immunoreactive fibers in the medial preoptic nucleus of the rat. J Comp Neurol 1984;225:151-66. [PubMed: 6373846]

Stauffer SR, Coletta CJ, Tedesco R, Nishiguchi G, Carlson KE, Sun J, Katzenellenbogen BS, Katzenellenbogen JA. Pyrazole ligands: structure-affinity/activity relationships and estrogen receptor alpha agonists. J Med Chem 2000;43:4934-4947. [PubMed: 11150164]

Stein V, Hermans-Borgmeyer I, Jentsch TJ, Hubner CA. Expression of the KCl cotransporter KCC2 parallels neuronal maturation and the emergence of low intracellular chloride. J Comp Neurol 2004;468:57-64. [PubMed: 14648690]

Sun D, Murali SG. Na+-K+-2Cl- cotransporter in immature cortical neurons: A role in intracellular $\mathrm{Cl}$ - regulation. J Neurophysiol 1999;81:1939-1948. [PubMed: 10200228]

Toran-Allerand CD, Tinnikov AA, Singh RJ, Nethrapalli IS. 17alpha- estradiol: a brain-active estrogen? Endocrinology 2005;146:3843-3850. [PubMed: 15947006]

Von Schassen C, Fester L, Prange-Kiel J, Lohse C, Huber C, Bottner M, Rune GM. Oestrogen synthesis in the hippocampus: role in axon outgrowth. J Neuroendocrinol 2006;18:847-856. [PubMed: 17026534]

Xia Z, Storm DR. The role of calmodulin as a signal integrator for synaptic plasticity. Nature Neurosci 2005;6:267-276.

Zhang JM, Konkle AT, Zup SL, McCarthy MM. Impact of sex and hormones on new cells in the developing rat hippocampus: a novel source of sex dimorphism? Eur J Neurosci 2008;27:791-800. [PubMed: 18333959] 

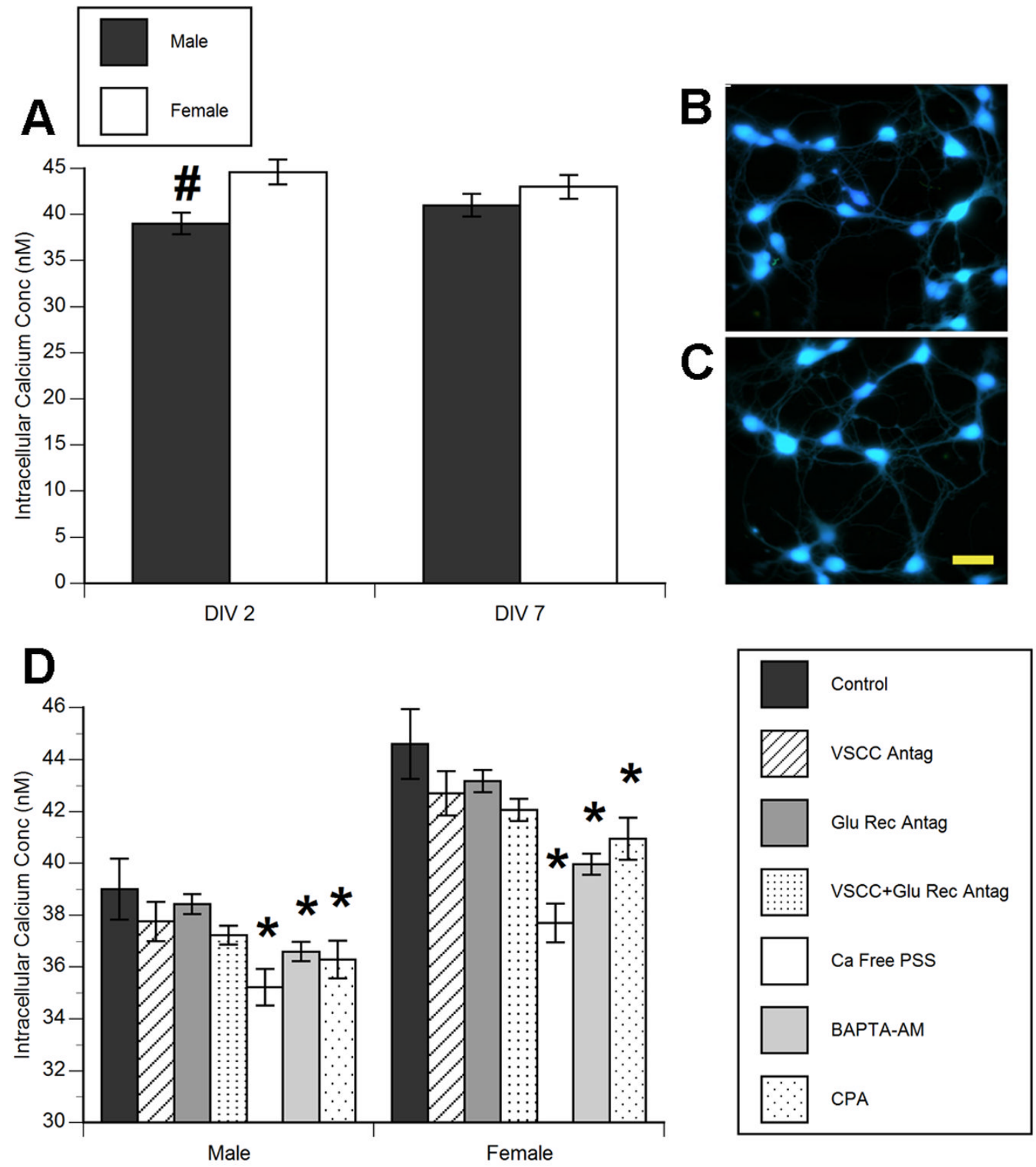

Figure 1. Effect of sex and age on resting intracellular calcium concentration in developing hippocampal neurons

(A) Mean baseline (resting) intracellular calcium concentration $\left(\left[\mathrm{Ca}^{2+}\right]_{\mathrm{i}}\right)$ on day in vitro 2 and 7 in male and female hippocampal neurons. On day in vitro 2 (DIV2), females had a significantly elevated baseline $\left[\mathrm{Ca}^{2+}\right]_{\mathrm{i}}$ as compared to males (Tukey's, \#p<0.05). Data represent mean \pm SEM $\left[\mathrm{Ca}^{2+}\right]_{i}$, with data obtained from 5-6 culture runs, with two to three fields of view per culture run for a total $n$ of 10-12. \# indicates significant difference from DIV2 female cultures.

(B) Representative pseudocolored image of baseline $\left[\mathrm{Ca}^{2+}\right]_{i}$ male hippocampal neurons on DIV 2. 
(C) Representative pseudocolored image of baseline $\left[\mathrm{Ca}^{2+}\right]_{\mathrm{i}}$ female hippocampal neurons on DIV 2. Scale bar $=20 \mu \mathrm{m}$.

(D) Effect of numerous regulators of intracellular calcium. Treatment with the ionotropic glutamate receptor antagonists AP5, MK-801, NBQX and NAS (100 $\mu \mathrm{M}$ of each antagonist), voltage sensitive calcium channel antagonist, diltiazem $(10 \mu \mathrm{M})$, extracellular calcium chelator EGTA $(500 \mu \mathrm{M})$ in the presence of calcium free physiological saline solution, intracellular calcium chelator BAPTA-AM $(1 \mu \mathrm{M})$, and intracellular calcium re-uptake inhibitor CPA $(1 \mu \mathrm{M})$ were assessed for their impact on resting intracellular calcium levels in male and female cultured hippocampal neurons on DIV 2. The baseline $\left[\mathrm{Ca}^{2+}\right]_{\mathrm{i}}$ in both male and female hippocampal neurons was significantly reduced by the intracellular calcium chelator BAPTAAM and CPA (Tukey's, *p<0.05). However, addition of these agents did not eliminate the sex difference in baseline $\left[\mathrm{Ca}^{2+}\right]_{\mathrm{i}}$. Blockade of extracellular sources of calcium (observed following calcium free PSS + EGTA treatment) likewise significantly reduced baseline $\left[\mathrm{Ca}^{2+}\right]_{\mathrm{i}}$ (Tukey's, ${ }^{*} \mathrm{p}<0.05$, significant difference from vehicle treated cultures within the same sex), and eliminated the sex difference in baseline intracellular calcium concentration by reducing females baseline $\left[\mathrm{Ca}^{2+}\right]_{\mathrm{i}}$ to the level of males. These data are interpreted as indicating the sex difference in resting $\left[\mathrm{Ca}^{2+}\right]_{\mathrm{i}}$ is due to increased influx from external sources in females. Data represent the mean \pm SEM $\left[\mathrm{Ca}^{2+}\right]_{\mathrm{i}}$ value, from a total of five culture runs, with one to two fields of view per culture run, providing an overall $n$ of 5 to 10 per group. 

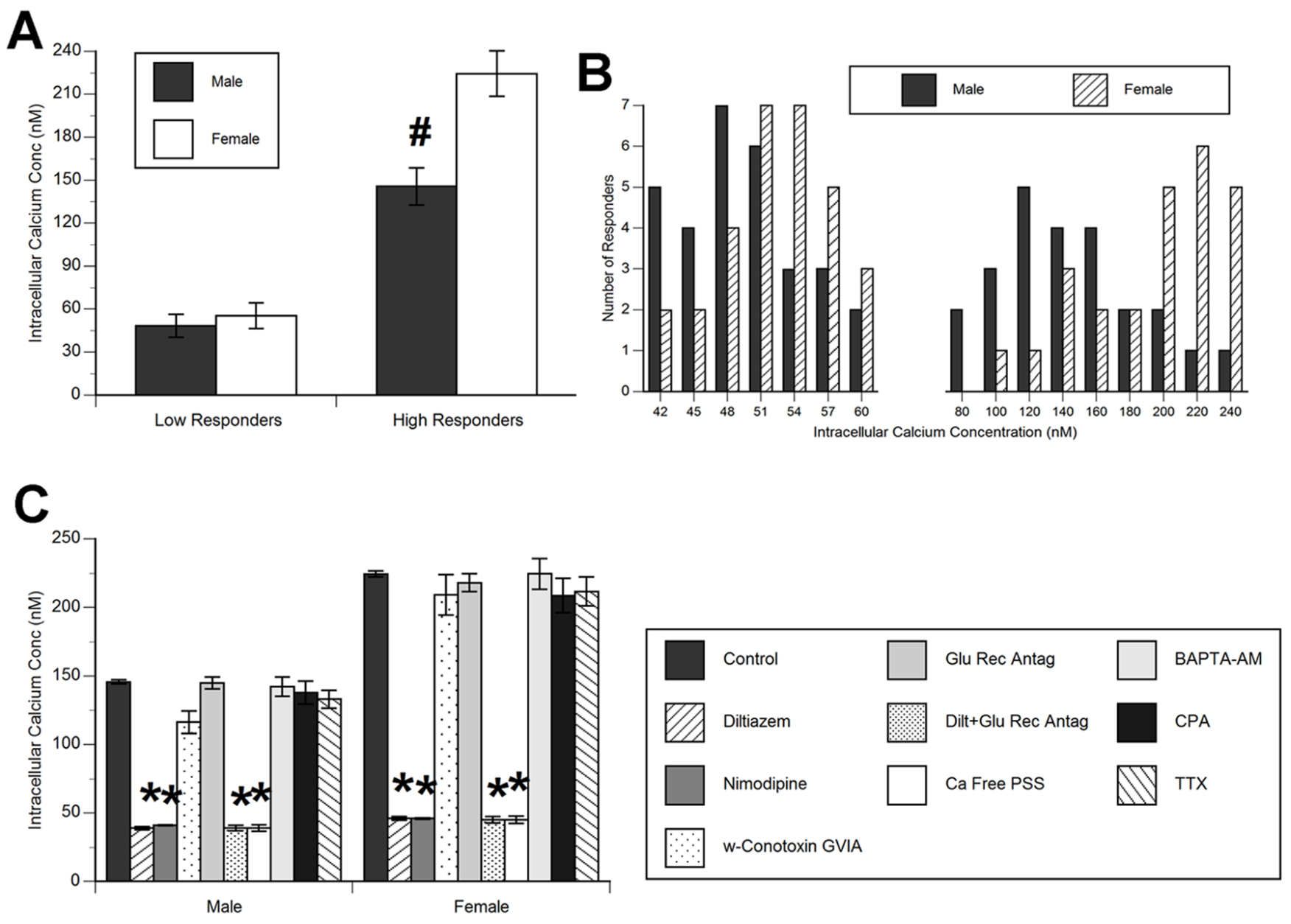

Figure 2. Effect of sex on peak magnitude of muscimol-induced calcium transients in developing hippocampal neurons

(A) There was a significant sex difference in the maximal increase in $\left[\mathrm{Ca}^{2+}\right]_{\mathrm{i}}$ following muscimol $(10 \mu \mathrm{M})$ application in hippocampal neurons on day in vitro 2 in cells classified as "high" responders (greater than 75\% increase over baseline; ANOVA; \#p<0.01. significant difference from females), but not in cells classified as "low" responders (less than $75 \%$ but greater than $10 \%$ increase over baseline). Data represent mean $\pm \mathrm{SEM}$ peak $\left[\mathrm{Ca}^{2+}\right]_{\mathrm{i}}$ value, with data obtained across 3 culture runs, with two fields of view per culture run, providing an overall $\mathrm{n}$ of 6 per group.

(B) Histogram of calcium responses from individual male and female hippocampal neurons. Visual inspection of the distribution pattern illustrates the distinction between "high" and "low" responding neurons. Data were obtained from 55 responding male and female hippocampal neurons.

(C) Effect of antagonizing the muscimol-induced increase in $\left[\mathrm{Ca}^{2+}\right]_{\mathrm{i}}$ in "high" responding hippocampal neurons by blockade of ionotropic glutamate receptors using the NMDA antagonists AP5 and MK-801, the AMPA antagonists NBQX and NAS $(100 \mu \mathrm{M}$ of each antagonist), voltage sensitive calcium channel blocker diltiazem $(10 \mu \mathrm{M})$, extracellular calcium entry using a combination of the calcium chelator EGTA $(500 \mu \mathrm{M})$ in the presence of calcium free physiological saline solution, intracellular calcium release using the calcium chelator BAPTA-AM $(1 \mu \mathrm{M})$, intracellular calcium re-uptake using the inhibitor CPA $(1 \mu \mathrm{M})$ and sodium channels using tetrodotoxin $(1 \mu \mathrm{M})$. There was a significant main effect of antagonist treatment on response to muscimol application in male and female hippocampal neurons on 
DIV 2 (ANOVA: $\mathrm{p}<0.03$ ). Antagonists of both voltage sensitive calcium channels and extracellular calcium entry significantly eliminated the muscimol-induced increase in $\left[\mathrm{Ca}^{2+}\right]_{\mathrm{i}}$ in both male and female hippocampal neurons (Tukey's, ${ }^{*} \mathrm{p}<0.01$, significant difference from vehicle treated cultures of the same sex), indicating the source of muscimol-induced calcium is the same for both sexes. Data represent mean \pm SEM peak $\left[\mathrm{Ca}^{2+}\right]_{\mathrm{i}}$ value, obtained across 3 to 4 culture runs, with two fields of view per culture run for an $n$ of 4 to 8 per group. 

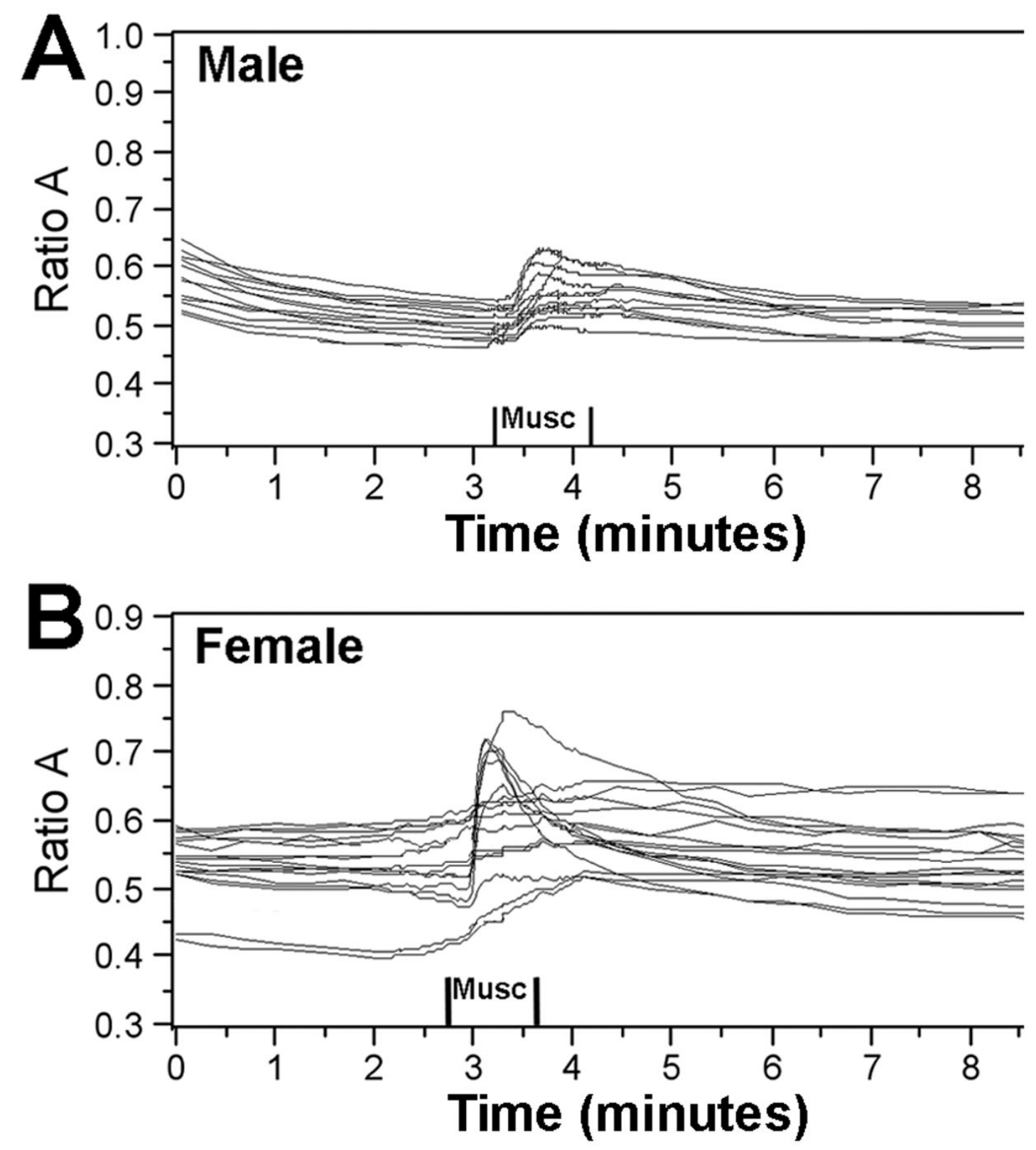

Figure 3.

Representative calcium responses from individual (A) male and (B) female hippocampal neurons. Responses were obtained from one individual field of view, documenting alterations in $\left[\mathrm{Ca}^{2+}\right]_{\mathrm{i}}$ following transient muscimol $(10 \mu \mathrm{M})$ administration. 

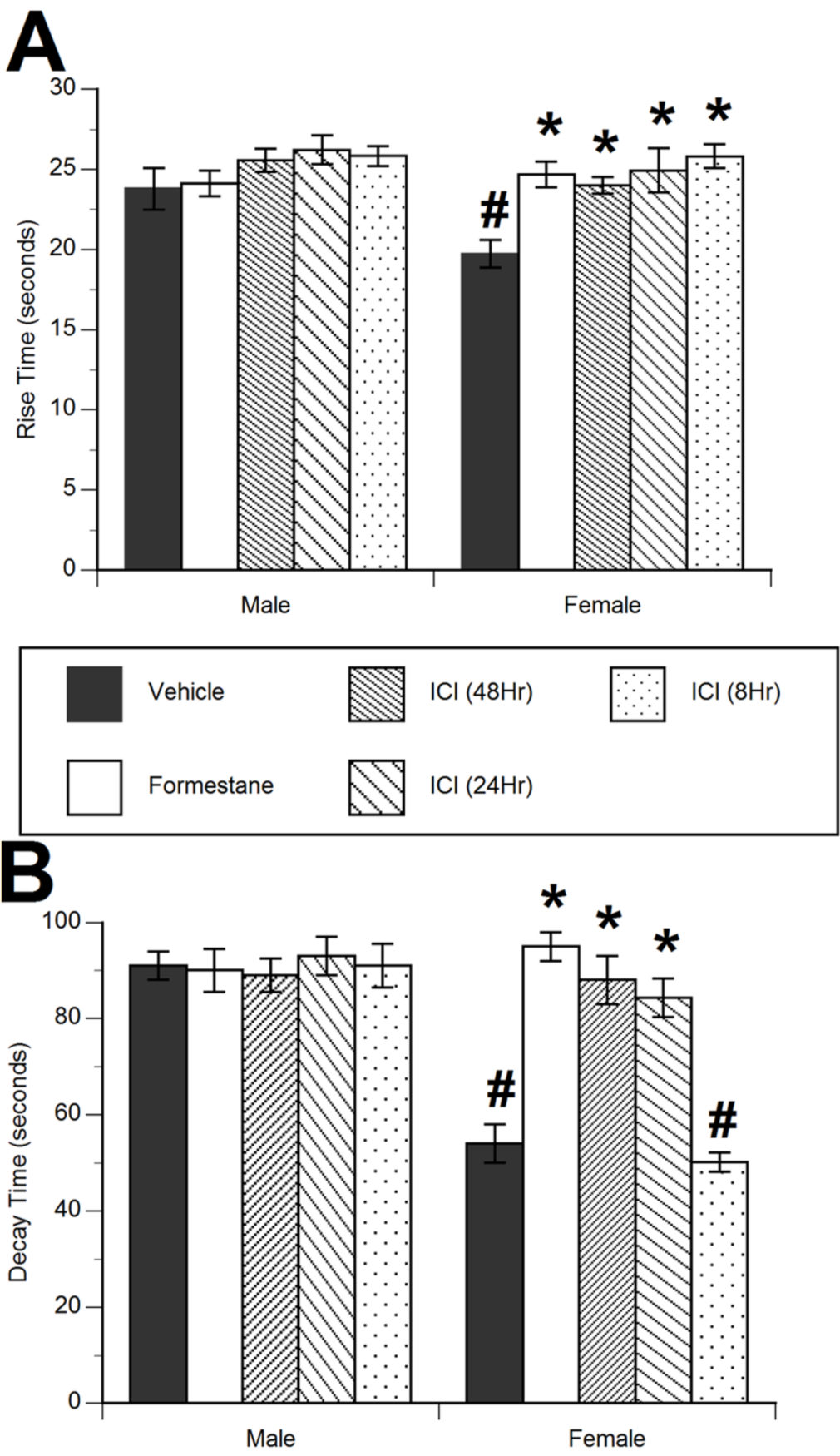

Figure 4. Time to and duration of elevated intracellular calcium post muscimol application are affected by inhibiting estradiol synthesis or antagonizing the estrogen receptor

(A) Female hippocampal neurons on DIV 2 had significantly faster rise time to peak intracellular calcium concentration subsequent to muscimol administration compared to all other groups (Tukey's, \#p<0.01, significant difference from male vehicle treated cultures), which was significantly reduced to the level of male hippocampal neurons by treatment with both the estrogen receptor antagonist ICI 182,780 (8, 24 and 48 hour pretreatment) and the estradiol synthesis inhibitor formestane (48 hour pretreatment) (Tukey's, $* \mathrm{p}<0.01$, significant difference from vehicle treated cultures of the same sex). Data represent mean \pm SEM time to peak $\left[\mathrm{Ca}^{2+}\right]_{\mathrm{i}}$, with data obtained across three culture runs, with two fields of view per culture 
run for an $\mathrm{n}$ of 6 per group. Muscimol was applied for 50 seconds, with the time to the greatest increase $\left[\mathrm{Ca}^{2+}\right]_{\mathrm{i}}$ during the 50 second administration window analyzed.

(B) Female (vehicle and 8 hour ICI 182,780 pretreatment) hippocampal neurons on DIV 2 had significantly faster decay time than all other groups (Tukey's, $\# \mathrm{p}<0.01$, significant difference from male vehicle treated cultures), which was significantly reduced to the level of male hippocampal neurons by treatment with both ICI 182,780 (24 and 48 hour pretreatment) and formestane (48 hour pretreatment) (Tukey's, ${ }^{*} \mathrm{p}<0.01$, significant difference from vehicle treated cultures of the same sex.). Data represent mean \pm SEM duration of $\left[\mathrm{Ca}^{2+}\right]_{\mathrm{i}}$ response, with data obtained across three culture runs, with one to two fields of view per culture run for an $n$ of 4 to 6 per group. The decay time was the time following muscimol application (i.e. the start of PSS administration) required to re-attain one-half baseline intracellular calcium concentration. 

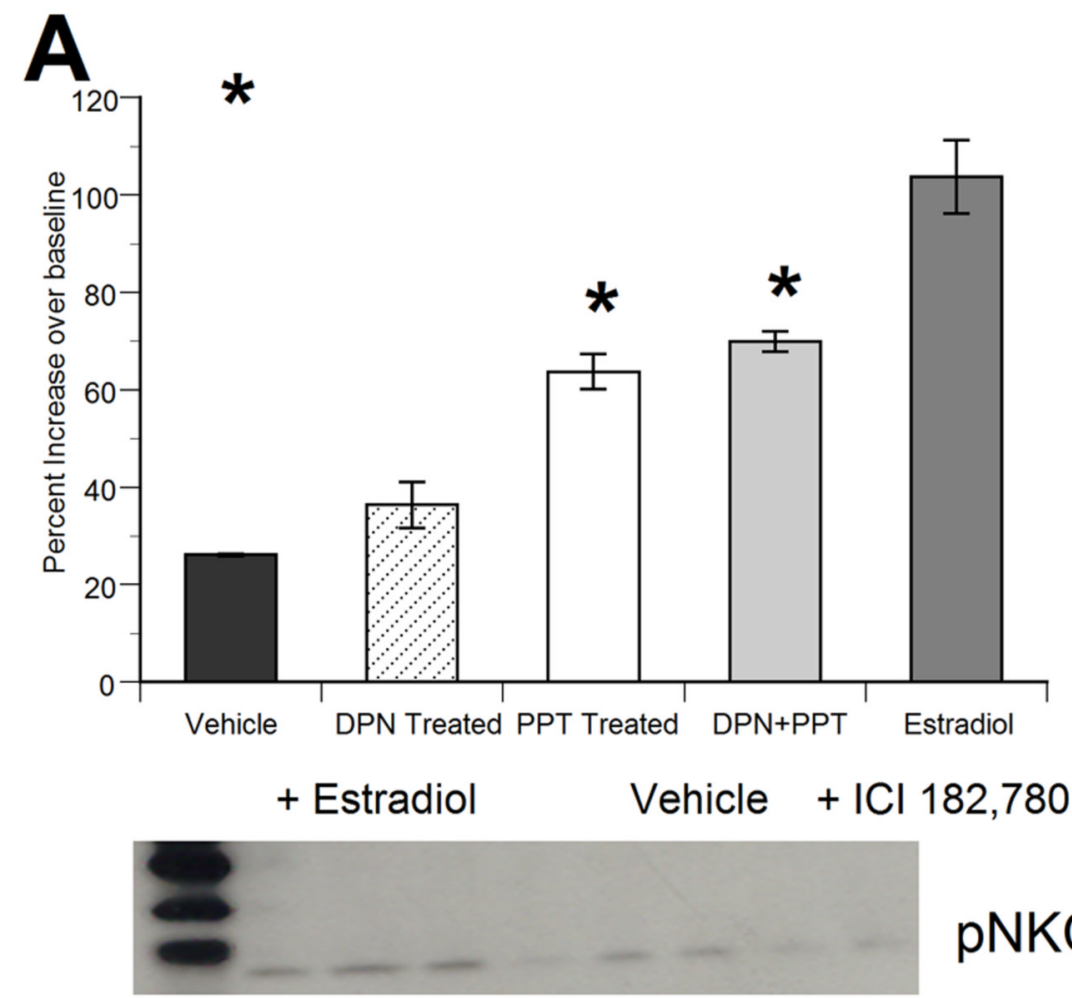

pNKCC

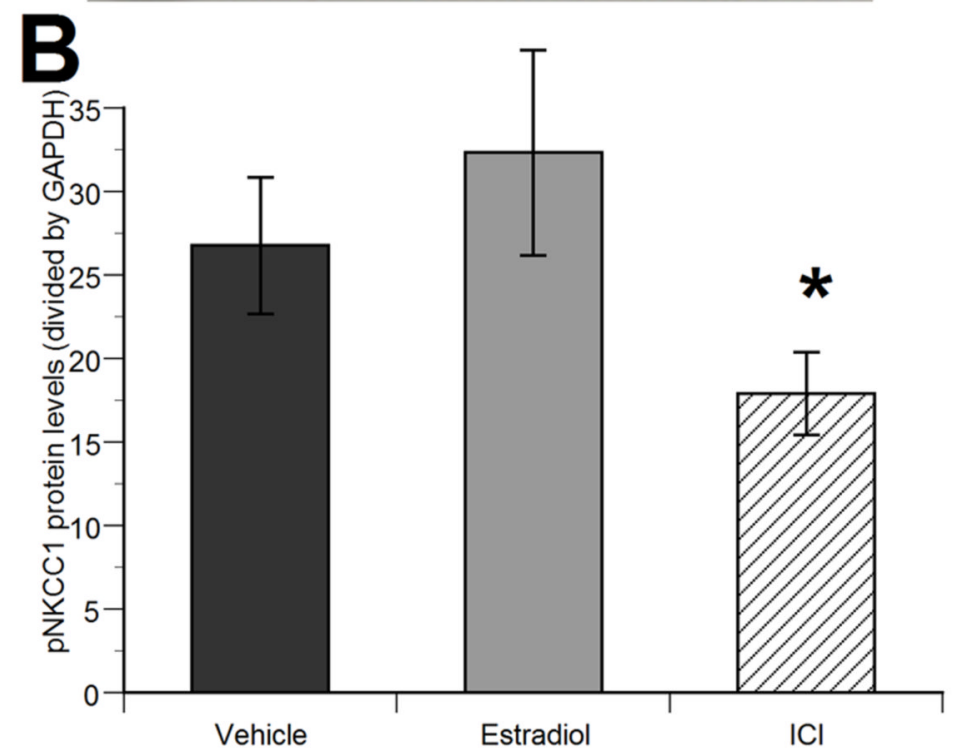

Figure 5. Estrogen receptor activation and estradiol synthesis affect excitatory GABA responses in the developing female hippocampus

(A) Female hippocampal neurons on DIV 2 show enhanced muscimol-induced calcium response following pretreatment with $17 \beta$-estradiol relative to all other groups (Tukey's, ${ }^{*} \mathrm{p}<0.01$, significant difference from vehicle treated cultures). Pretreatment with the selective estrogen receptor a agonist PPT likewise increased the magnitude of muscimol-induced calcium responses (Tukey's, \#p<0.05), with no effect of the selective estrogen receptor $\beta$ agonist DPN. Data represent mean \pm SEM peak $\left[\mathrm{Ca}^{2+}\right]_{i}$ value, data obtained across 3 culture runs, with one to two fields of view per culture run, providing an overall $n$ of 4 to 6 per group. 
(B) Hippocampal cells from DIV 2 female cultures show significantly attenuated levels of the phosphorylated form of the chloride co-transporter, $\mathrm{pNKCC} 1$, following pretreatment with the estrogen receptor antagonist, ICI 182,780, relative to all other groups (Tukey's, ${ }^{*} \mathrm{p}<0.05$, significant difference from vehicle treated cultures). Pretreatment with $17 \beta$-estradiol produced a marginal effect (Tukey's, $\mathrm{p}<0.07$ ). Data are expressed as grayscale integrative area density/ GAPDH (means \pm SEM, $n=6$ per group across two culture runs). 